\title{
Crop Water Requirements Analysis Using Cropwat 8.0 Software in Maize Intercropping with Rice and Soybean
}

\author{
Edy Suryadi $^{\# 1}$, Dedi Ruswandi ${ }^{*}$, Sophia Dwiratna ${ }^{\#}$, Boy Macklin Pareira Prawiranegara ${ }^{\#}$

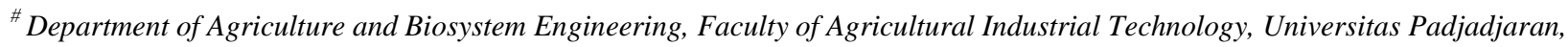 \\ Jl. Raya Bandung - Sumedang Km.21, 43563 Jatinangor Sumedang, Indonesia \\ E-mail: ${ }^{\# 1}$ edy_suryadi2010@yahoo.co.id \\ *Department of Agrotechnology, Faculty of Agriculture, Universitas Padjadjaran, Jl. Raya Bandung - Sumedang Km.21, 43563 \\ Jatinangor Sumedang, Indonesia \\ E-mail: dedi.ruswandi@unpad.ac.id
}

\begin{abstract}
The increasing level of land conversion from fertile farmland towards infrastructural purposes land such as residential and industrial land results in the devolving of the expansion of maize area from fertile land to land marginal. Maize is one of the crops that is being targeted for development planning in the food and agriculture sector. To improve food self-sufficiency, especially maize, commodity, proper management of the production processes such as crop water requirement and the intercropping pattern is needed. The purpose of this study is to find out how much water needs of plants in intercropping maize with rice, and intercropping corn with soybeans. To intensify food self-sufficiency especially maize commodities, proper management of the production process is required such as crop water requirements and intercropping patterns aspects. The purpose of the research is to find out the value of crop water requirements in intercropping maize with rice, as well as intercropping maize with soybeans. This research uses a descriptive method which describes the crop water requirement affecting the productivity using software Cropwat 8.0. The results show that crop water requirements of maize in intercropping with rice is $406.3 \mathrm{~mm}$ while water requirement with soybean intercropping is $408.6 \mathrm{~mm}$ during the growing season. The average productivity of maize intercropping with rice was $7.454 \mathrm{ton} / \mathrm{ha}$ of a dry kernel, whereas, in intercropping maize with soybean, productivity value of maize is 7.88 ton/ha of a dry kernel. The best combination, according to the productivity and the crop water requirement, is the maize intercropping with soybean. The difference in productivity is up to 5.7 percent with only $2.3 \mathrm{~mm}$ additional water demand for maize and intercropping rice plants.
\end{abstract}

Keywords — crop water requirement; Cropwat 8.0; Rice; Soybean; Intercropping.

\section{INTRODUCTION}

Maize (Zea mays L.) is one of the grain crops of the grass family[1] and the world's most important crops besides rice and wheat[2], [3]. Food demand will continue to increase in line with the increasing population of Indonesia. According to data from the Indonesian Statistical Center in 2013, the 2010 population census showed that the number of Indonesian population was 237.6 million inhabitants[4]-[6]. Based on the last 10-year data, the population increased with an annual growth rate of about 1.49 percent. Maize has the potential to help secure the food supply especially to accomplish the food diversity. Maize is one of the crops that becomes the target of development planning in the field of food and agriculture and includes in the national food selfsufficiency plan in Indonesia until 2019[5], [6].

The land conversion from fertile lands to settlements and industries raise the expansion of maize cultivation areas to marginal lands. These marginal lands can reduce crop productivity due to environmental stresses such as drought or nutrient deficiency. However, the marginal lands in Indonesia have an enormous potential large potential land area. The marginal land area was approximately 100 million hectares included dry land, tidal land, and peat land. In West Java Province, over one million hectares dry land has been potentially utilized with appropriate management and technology.

Increasing the intensity of land use will increase the yield of maize. Unpredictable rainfall severely limits the intensity of land use. Implementation of integrated farming pattern about climate aspect is crucial [7], [8]. Double cropping system has been introduced to various crops through crop rotation or intercropping. Maize-soybean intercropping and sweetcorn-chili pepper intercropping is suitable to increase the intensity of land use[9], [10]. 
By analyzing the crop water requirement, a selection of treatments can be determined in maize and paddy crops or in intercropping with soybean to produce maximum production and the volume of water that can be saved during the intercropping cultivation period can be predicted [11]. Factors affecting the value of the crop water requirement are the value of Crop Coefficient (Kc) and potential evapotranspiration value (ETo)[12], [13]. Evapotranspiration (ET) is a combination of two processes of evaporation and transpiration. Evaporation is the process of evaporation or loss of water from soil and water bodies (abiotic), while transpiration is the process of water discharge from plants (biotic) due to the process of respiration and photosynthesis[14]-[16]. The combination of two separate processes where water loss from the soil surface through evaporation and water loss from plants through transpiration.

One way to determine the crop water requirement one is by utilizing software Cropwat 8.0 compiled by FAO[15]. The water requirement of the plant can be determined by the estimation method, where the estimation of the water requirement of the plant (ETc) is equal to the potential evapotranspiration value (ETo) multiplied by the crops coefficient $(\mathrm{Kc})$. The Penman-Monteith equation is used in determining the potential evapotranspiration value in Cropwat 8.0 [12], [17]-[21]. Main factors that determine the potential evapotranspiration value in the Monteith Penman equation are temperature, solar radiation, wind velocity, air humidity, and ambient temperature. By using Cropwat 8.0 software, we can find out the needs of crop water during the growing season by utilizing irrigation from rainwater in field research.

\section{MATERIAL AND METHODS}

\section{A. Materials}

The research was conducted in the Agriculture Research and Development Center of Universitas Padjadjaran in Arjasari, Bandung West Java Indonesia at February - July 2016. The method used in this research is a descriptive method that compares the crop water requirement based on a calculation by using software Cropwat 8.0 in intercropping maize with rice, and also in intercropping maize with soybean. Observation of maize productivity in tons/ha was conducted to see the correlation with the crop water requirement.

Data of rainfall in the last ten years were obtained from at least three rainfall stations located in around the District Arjasari. The stations used for calculating the precipitation area on the intercropping. Maize with rice was Cipaku Station, Ciherang Station, and Cibeureum Station, while on the intercropping maize with soybean were Cipaku, Ciherang, and Cileunca stations.

Climate data for the last ten years in the period 2006 2015 were obtained from the Meteorology, Climatology, and Geophysics Class I Bandung. Climatological data required were maximum temperature, minimum temperature, wind speed, air humidity, and the duration of solar irradiation. All the data were calculated to get the average for the last ten years.

Cropwat is a software released by FAO (Food and Agriculture Organization) to facilitate the analysis of irrigation water needs and schedule. As input data, some basic data is needed in the form of climatological data, monthly rainfall data, plant data, and soil physical properties data.

\section{B. Method}

To obtain the value of crop water requirement using Cropwat 8.0 software as follows:

1) Input climatological data: Input climatological data in the form of a minimum and maximum temperature, air humidity $(\%)$, wind speed $(\mathrm{m} / \mathrm{s})$, and the duration of solar irradiation $(\%)$ included the altitude, latitude and longitude value of research location that represents Arjasari Subdistrict. The data were collected for ten years (2006-2015) from the Meteorology, Climatology, and Geophysics Class I Bandung. In this step, ETo value on every month or ETo per day can be obtained. The ETo values obtained are based on Penman Monteith's Method

2) Input monthly rainfall amount data in the Rain section. Rainfall data becomes one of the factors that determine the value of crop water requirement. Rainfall data used is for the last ten years in the period 2006 - 2015. At the location of the study. There is no rainfall station so that the use of regional rainfall. In determining the precipitation area used Polygon Thiessen method. To get the value of rainfall area by using Polygon Thiessen method need at least rainfall data from 3 rainfall station: Cipaku, Ciherang, and Cibeureum Station. By utilizing the map of Citarum watershed. The area can be determined the vast of each polygon. Location of research was determined based on coordinate points on the map. Data processing is done by calculating the average monthly rainfall data for ten years of data available. At this stage, an effective rainfall value is obtained based on the FAO method with AGWL formula. If the amount of rain is more than $70 / 3 \mathrm{~mm}$, then the rain effectivity value can be calculated by the equation: Peff = $0.8 * \mathrm{P}-24 / 3$.

3) Input crop characteristic data: Input crop characteristic data include the number of days at each growth phase, Kc value at each growth phase, root depth, critical depletion value, and crop yield response factor. The yield response factor $(\mathrm{Ky})$ is the ratio of relative yield reduction to relative evapotranspiration deficit that integrates the weather, crop and soil conditions that make crop yield less than its potential yield in the face of deficit evapotranspiration.

4) Input soil characteristic data: Input soil characteristic data in Arjasari sub-district based on soil physical characteristic test result. The software needs some general soil data like total available soil moisture, maximum rain infiltration rate, maximum rooting depth, initial soil moisture depletion, and initially available soil moisture.

5) Obtaining the value of daily crop water needs (ETc), ETc/decade: After entering all the data on each required component, the value of daily crop water needs (ETc), ETc/decade value can be obtained. In addition to the ETc value in the Crop Water Requirement menu (CWR), the amount of irrigation required on each crop stage is displayed. 


\section{RESULT AND DISCUSSIONS}

\section{A. Reference Evapotranspiration}

Potential evapotranspiration value based on the calculations using Cropwat 8.0, the potential evapotranspiration values are listed in Table I.The highest potential evapotranspiration value occurring in September of $4.62 \mathrm{~mm} /$ day or $138.99 \mathrm{~mm} / \mathrm{month}$. During the highest potential evapotranspiration planting season occurs in March of $3.71 \mathrm{~mm} /$ day or $114.89 \mathrm{~mm} /$ month. If the value of evapotranspiration is high, then there is high evaporation also so that the amount of crop water requirement will be higher. Conversely, if evapotranspiration is low, the crop water requirement will be small.

The dominant factors affecting evapotranspiration are solar thermal radiation and temperature, relative humidity and the wind, and in general, the magnitude of evapotranspiration will increase as temperature, solar thermal radiation, humidity, and wind speed grow larger. The effect of solar thermal radiation on evapotranspiration is through the process of photosynthesis. In regulating the life of the plant requires the circulation of water through the root-stem-leaf system. The circulation of the water travel from the bottom (roots) to the top (leaves) is accelerated with an increasing amount of solar thermal radiation to the vegetation concerned.

The effect of temperature on evapotranspiration can be said to be directly related to the intensity and duration of solar radiation. The hotter and drier climate change which involved an increase in mean air temperature with a reduction in rainfall amount caused a higher yield reduction [22], [23]. The impact of higher temperatures on maize yield might also be related to the reduction of kernel set. Maize yield could reduce due to exposure to above optimal temperature threshold [24], [25]. For example, photosynthesis was reported to perform better within the optimal limit while maintenance respiration increased with an increase in temperature which could reduce the growth of the plant by limiting assimilate supply [25]. However, further research is needed that the temperature that will affect the evapotranspiration is the leaf temperature and not the air temperature around the leaves.

TABEL I

DAILY AND MONTHLY REFERENCE EVAPOTRANSPIRATION VALUE

\begin{tabular}{|l|c|c|}
\hline \multicolumn{1}{|c|}{ Month } & $\begin{array}{c}\text { ET } \\
\text { mm/day }\end{array}$ & $\begin{array}{c}\text { ET } \\
\text { mm/month }\end{array}$ \\
\hline January & 3.79 & 117.59 \\
\hline February & 3.86 & 108.01 \\
\hline March & 3.71 & 114.89 \\
\hline April & 3.80 & 114.09 \\
\hline May & 3.54 & 109.68 \\
\hline June & 3.40 & 102.14 \\
\hline July & 3.62 & 112.27 \\
\hline August & 4.24 & 131.35 \\
\hline September & 4.62 & 138.46 \\
\hline October & 4.35 & 134.99 \\
\hline November & 3.84 & 115.21 \\
\hline December & 3.91 & 121.18 \\
\hline \multicolumn{1}{|c|}{ Average } & $\mathbf{3 . 8 9}$ & $\mathbf{1 1 8 . 3 2}$ \\
\hline
\end{tabular}

The effect of the wind on evapotranspiration is through the mechanism of water removal vapor coming out from the pores of the leaf. The greater the wind speed. The greater the evapotranspiration arm that can occur. Compared with the effect of solar thermal radiation. The effect of the wind on the evapotranspiration rate is smaller. Soil moisture also has a role in influencing the occurrence of evapotranspiration. Evapotranspiration takes place when the vegetation is not in short supply water. In other words. Potential evapotranspiration takes place when the soil moisture conditions range from the point of wilting point and field capacity.

\section{B. Rainfall Data}

Based on data in Table II, the amount of rainfall in a year at the maize with intercropping rice area was $2.200 \mathrm{~mm}$ while the number of effective rain was $1.490 .6 \mathrm{~mm}$. This is the sum of the effective rainfall value each month. The peak rainy season was $346.0 \mathrm{~mm}$ occurred in December with the effective rainfall was $252.8 \mathrm{~mm}$. while the lowest rainfall was $30.0 \mathrm{~mm}$ occurred in August with the effective rainfall was $8.0 \mathrm{~mm}$. At the maize with soybean intercropping area. The amount of rainfall in a year was $2.083 .0 \mathrm{~mm}$ with the effective rainfall was $1.666 .4 \mathrm{~mm}$. The peak rainy season was $335.0 \mathrm{~mm}$ occurred in December with the effective rainfall was $268.0 \mathrm{~mm}$. while the lowest rainfall was 33.0 $\mathrm{mm}$ occurred in August with the effective rainfall was 26.4 $\mathrm{mm}$.

TABLE II

RAINFALL AND EFFECTIVE RAINFALL

\begin{tabular}{|c|c|c|c|c|}
\hline \multirow{2}{*}{ Month } & \multicolumn{2}{|c|}{$\begin{array}{c}\text { Maize with rice } \\
\text { Intercropping Area }\end{array}$} & \multicolumn{2}{c|}{$\begin{array}{c}\text { Maize with Soybean } \\
\text { Intercropping Area }\end{array}$} \\
\cline { 2 - 5 } & $\begin{array}{c}\text { Rainfall } \\
(\mathbf{m m})\end{array}$ & $\begin{array}{c}\text { Effective } \\
\text { Rainfall } \\
(\mathbf{m m})\end{array}$ & $\begin{array}{c}\text { Rainfall } \\
(\mathbf{m m})\end{array}$ & $\begin{array}{c}\text { Effective } \\
\text { Rainfall } \\
(\mathbf{m m})\end{array}$ \\
\hline Jan & 221.0 & 152.8 & 182.0 & 145.6 \\
\hline Feb & 218.0 & 150.4 & 224.0 & 179.2 \\
\hline March & 300.0 & 216.0 & 301.0 & 240.8 \\
\hline April & 294.0 & 211.2 & 275.0 & 220.0 \\
\hline May & 179.0 & 119.2 & 152.0 & 121.6 \\
\hline June & 68.0 & 30.8 & 64.0 & 51.2 \\
\hline July & 35.0 & 11.0 & 39.0 & 31.2 \\
\hline August & 30.0 & 8.0 & 33.0 & 26.4 \\
\hline Sept & 54.0 & 22.4 & 58.0 & 46.4 \\
\hline Oct & 146.0 & 92.8 & 124.0 & 99.2 \\
\hline Nov & 309.0 & 223.2 & 296.0 & 236.8 \\
\hline Dec & 346.0 & 252.8 & 335.0 & 268.0 \\
\hline Total & $\mathbf{2 2 0 0 . 0}$ & $\mathbf{1 4 9 0 . 6}$ & $\mathbf{2 0 8 3 . 0}$ & $\mathbf{1 6 6 6 . 4}$ \\
\hline
\end{tabular}

This data is obtained based on data processing over the last ten years (period 2006 - 2015). However, there are differences in results on the value of effective rain or $80 \%$ chance rainfall because of effective rainfall. This is rainfall that can be utilized by plants. Effective rainfall is the rainfall in an area and used for crops growth. 
Based on the classification of the climatic type according to Oldeman in maize with intercropping rice area experienced wet months(rainfall of more than $200 \mathrm{~mm}$ ) for four months in a row in January- April while experiencing dry months (rain less than $100 \mathrm{~mm}$ ) for four months in a row that is in June - September. The climate in 2006-2015 was included in climate type D3. While in the maze with soybean intercropping area experienced wet months for three months in a row in February- April. While experiencing dry months for four months in a row that is in June - September, the climate was also included in climate type D3. Climate type D3 means the area suitable for planting once a year depends on the irrigation supply.

\section{Crop Coefficient $(\mathrm{Kc})$}

Before determining the value of crop water requirement, crop coefficients $(\mathrm{Kc})$ data was needed. Different $\mathrm{Kc}$ values for each plant type. Kc values used in this study based on the $\mathrm{Kc}$ values listed in Table 12 in FAO Irrigation and Drainage Paper No. 56 Crop Evapotranspiration. In general, there are four phases in the growth stage consisting of the initial phase, development phase, mid-season phase, and late phase. While in FAO book the value of $\mathrm{Kc}$ is known only in three main phases that are the initial phase, mid phase, and the late phase. For the development phase, Kc was ranged between initial phase Kc values with mid-season phase Kc value. Kc data on maize and rice, as well as soybean. Are presented in Table III.

TABLE III

Crop Coefficient Value For Maize. Rice. AND SOYBEAN

\begin{tabular}{|c|c|c|}
\hline \multirow{2}{*}{ Crop } & Phase & $\begin{array}{c}\text { Crop Coefficient } \\
\text { (Kc) }\end{array}$ \\
\hline \multirow{3}{*}{ Maize } & Initial & 0.9 \\
\cline { 2 - 3 } & Mid & 1.2 \\
\cline { 2 - 3 } & End & 0.6 \\
\hline \multirow{3}{*}{ Soybean } & Initial & 0.4 \\
\cline { 2 - 3 } & Mid & 1.15 \\
\cline { 2 - 3 } & End & 0.5 \\
\hline \multirow{3}{*}{ Rice } & Initial & 1.1 \\
\cline { 2 - 3 } & Mid & 1.2 \\
\cline { 2 - 3 } & End & 1.05 \\
\hline
\end{tabular}

Source: Allen et al. 1998

For the Kc value in the development phase, it is assumed to be equal to the $\mathrm{Kc}$ value in the mid-season phase because the Kc value in this phase lies between the initial phase and the mid-season phase so that the highest value is $\mathrm{Kc}$ midseason. In general. The value of Kc of these two plants is not so significantly different; there is only a small difference between the values of $\mathrm{Kc}$ in each phase. In rice plants. The Kc value in the core and late phase is higher than that of corn. But in the development and mid-season. The value of Corn $\mathrm{Kc}$ is the same as the $\mathrm{Kc}$ value of rice.

Maize planting time was done two weeks after planting rice and soybeans as the insertion plant that is in the first decade of March. The crop coefficient of maize obtained based on data of Cropwat 8.0 software during planting season. $\mathrm{Kc}$ value in the initial phase constant is 0.9 entering the development phase the Kc value keeps increasing from 0.9 to 1.04 (Table IV). Kc in the mid-season phase is relatively constant at 1.3 . At the end of the mid-season phase until the end of the planting period. The value of $\mathrm{Kc}$ decreases.it is indicating that the amount of crop water requirement in the late-season phase is decreasing until the end of the growing season. The lowest $\mathrm{Kc}$ value was 0.66 when harvesting.

\section{Crop Water Requirement}

Crop water requirement is a given amount of water lost due to crop evapotranspiration (ETc). In other words. The value of the crop water requirement is given equally to the amount of plant evapotranspiration. The value of daily or decadal crop water requirements for maize intercropped with rice can be seen in Table IV.

TABLE IV

Crop Water Requirement Value (Etc) For Maize INTERCROPPED WITH RICE

\begin{tabular}{|c|c|c|c|c|c|}
\hline Month & Decade & Phase & Kc & $\begin{array}{c}\text { ETc } \\
\mathbf{m m} / \mathbf{d a y}\end{array}$ & $\begin{array}{c}\text { Etc } \\
\mathbf{m m} / \mathbf{d e c a d e}\end{array}$ \\
\hline March & 1 & Init & 0.9 & 3.38 & 3.4 \\
\hline March & 2 & Init & 0.9 & 3.34 & 33.4 \\
\hline March & 3 & Dev & 0.9 & 3.37 & 37.1 \\
\hline April & 1 & Dev & 0.96 & 3.61 & 36.1 \\
\hline April & 2 & Dev & 1.04 & 3.94 & 39.4 \\
\hline April & 3 & Mid & 1.11 & 4.13 & 41.3 \\
\hline May & 1 & Mid & 1.13 & 4.11 & 41.1 \\
\hline May & 2 & Mid & 1.13 & 4.01 & 40.1 \\
\hline May & 3 & Mid & 1.13 & 3.96 & 43.6 \\
\hline June & 1 & Late & 1.06 & 3.66 & 36.6 \\
\hline June & 2 & Late & 0.86 & 2.93 & 29.3 \\
\hline June & 3 & Late & 0.66 & 2.29 & 22.9 \\
\hline July & 1 & Late & 0.55 & 1.95 & 1.9 \\
\hline & & Total & & $\mathbf{4 0 6 . 3}$ \\
\hline
\end{tabular}

The result of data processing with Cropwat 8.0 shows different $\mathrm{Kc}$ value in each decade. If the input data value of $\mathrm{Kc}$ was the biggest is 1.2 after the obtained result turns out the highest value of $\mathrm{Kc}$ is 1.13 in a mid-season phase that is during the third decade of April until May.

The largest crop water requirement occurs in the midseason phase, which is the third decade of May. While the lowest water demand value occurs in the late-season phase because at this time the plants are ripe perfect so that the required water is not much needed. The plants need the most water when it occurs in the process of forming the fruit as requires more energy to make fruit formation in the phase towards the late-season. The value of water demand is reduced because of the process of fruit ripening. The growth of the crop has been maximized so that no longer develop the growth process and approaching the harvest phase. The crop will dry out. 
The amount of maize crop water requirement during the growing season is $406.3 \mathrm{~mm}$. The value considered to be normal because the water requirement of maize is about 400 $\mathrm{mm}$ to $700 \mathrm{~mm}$. The value obtained is the minimum requirement because of the high rainfall happened and the water requirement is sufficient. The water demand in the initial to mid-season phase is increasing despite the decline in the crop water requirement in the first decade of April. During the mid-season phase. The crop water requirement was relatively equal towards the late-season phase. The water demand decreases to the lowest point at harvest time. The crop water requirement for rice also needed to be calculated as in the intercropping system. Rice plants have different growth phases with other plants where there are two phases before the initial phase. The nursery phase. And land preparation. The nursery was directly done in the field so that the growth phase starts from the phase of land preparation.

TABLE V

CROP WATER REQUIREMENT VALUE OF RICE

\begin{tabular}{|c|c|c|c|c|c|}
\hline Month & Decade & Phase & Kc & $\begin{array}{c}\text { ETc } \\
\text { mm/day }\end{array}$ & $\begin{array}{c}\text { ETc } \\
\text { mm/dec }\end{array}$ \\
\hline February & 1 & $\begin{array}{c}\text { Land } \\
\text { Prep }\end{array}$ & 1.05 & 4.03 & 24.2 \\
\hline February & 2 & $\begin{array}{c}\text { Land } \\
\text { Prep }\end{array}$ & 1.05 & 4.05 & 40.5 \\
\hline February & 3 & Initial & 1.07 & 4.09 & 32.7 \\
\hline March & 1 & Initial & 1.1 & 4.13 & 41.3 \\
\hline March & 2 & Initial & 1.1 & 4.08 & 40.8 \\
\hline March & 3 & Dev & 1.1 & 4.12 & 45.3 \\
\hline April & 1 & Dev & 1.11 & 4.2 & 42 \\
\hline April & 2 & Dev & 1.13 & 4.29 & 42.9 \\
\hline April & 3 & Dev & 1.14 & 4.24 & 42.4 \\
\hline May & 1 & Mid & 1.15 & 4.19 & 41.9 \\
\hline May & 2 & Mid & 1.16 & 4.09 & 40.9 \\
\hline May & 3 & Mid & 1.16 & 4.04 & 44.4 \\
\hline June & 1 & Mid & 1.16 & 3.99 & 39.9 \\
\hline June & 2 & Late & 1.16 & 3.93 & 39.3 \\
\hline June & 3 & Late & 1.13 & 3.94 & 39.4 \\
\hline July & 1 & Late & 1.1 & 3.9 & 39 \\
\hline July & 2 & Late & 1.07 & 3.86 & 38.6 \\
\hline July & 3 & Late & 1.03 & 3.95 & 35.6 \\
\hline & & Total & & $\mathbf{7 1 1 . 3}$ \\
\hline
\end{tabular}

The number of days during the rice growth to harvest phase is 155 days starting from the third day of February to the third day of July. The rice growth phase begins during the initial phase to the late-season phase. The land preparation phase is necessary to calculate the crop water requirements during the preparation of the land to grow rice. The length of the initial phase day is 30 days, the development phase is 40 days, and the mid-season phase is 45 days as well as the late-season phase for 40 days.

For rice the value of the crop water requirement will be different at each phase where it's affecting value is $\mathrm{Kc}$ and the number of days in each growth phase. The value of crop water requirements in each growth phase for rice is shown in
Table V. The highest crop water requirement occurs in the development phase that is on the third decade of May with the value of water requirement of $45.3 \mathrm{~mm}$ while the lowest water demand during the growth phase occurred in the initial phase of $32.7 \mathrm{~mm}$. At this phase. The plant has not grown so that the water needs were low.

The crop needs the most water when it occurs in the process of forming the fruit because the plant body is getting bigger and requires more energy for the process of filling the grain of rice. In the phase towards the late-season. The water demand is reduced because at this time the fruit/grain ripening. The growth of the plant has been maximized so that the growth process stopped. The amount of rice water requirement during the planting period from February to the end of July is 711.3 the value of crop water requirement for rice with long life was ranged between $720 \mathrm{~mm}-2.160 \mathrm{~mm}$. The value obtained was less than the standard in general. But close to the minimum value of the water needs of rice. The rainfall occurs large enough that the water requirements become less.

TABLE VI

CROP WATER REQUiREMENT VALUE (ETC) For INTERCROPPING OF MAIZE WITH SOYBEANS

\begin{tabular}{|c|c|c|c|c|c|}
\hline \multirow{2}{*}{ Month } & \multirow{2}{*}{$\begin{array}{c}\text { Decad } \\
\text { e }\end{array}$} & \multirow{2}{*}{$\begin{array}{c}\begin{array}{c}\text { ETc } \\
\text { (Maize) }\end{array} \\
\mathbf{m m} \\
\end{array}$} & \multirow{2}{*}{ Month } & \multirow{2}{*}{$\begin{array}{l}\text { Decad } \\
\text { e }\end{array}$} & \multirow{2}{*}{$\begin{array}{c}\begin{array}{c}\text { ETc } \\
\text { (Soybean) }\end{array} \\
\mathbf{m m} \\
\end{array}$} \\
\hline & & & & & \\
\hline March & 1 & 3.34 & February & 3 & 1.5 \\
\hline March & 2 & 33.4 & March & 1 & 15 \\
\hline March & 3 & 37.1 & March & 2 & 18.5 \\
\hline April & 1 & 36.3 & March & 3 & 39.3 \\
\hline April & 2 & 39.7 & April & 1 & 41.9 \\
\hline April & 3 & 41.6 & April & 2 & 42.3 \\
\hline May & 1 & 41.4 & April & 3 & 41.2 \\
\hline May & 2 & 40.4 & May & 1 & 39.8 \\
\hline May & 3 & 43.8 & May & 2 & 27.7 \\
\hline June & 1 & 36.8 & May & 3 & 5.3 \\
\hline June & 2 & 29.5 & \multirow{4}{*}{\multicolumn{2}{|c|}{ Total }} & \multirow{4}{*}{272.4} \\
\hline June & 3 & 23.1 & & & \\
\hline July & 1 & 2 & & & \\
\hline \multicolumn{2}{|c|}{ Total } & 408.6 & & & \\
\hline
\end{tabular}

It can be seen from the graph that the value of the crop water requirement of each decade is up and down this happens because of the different potential evapotranspiration value in each decade. In the initial phase until the beginning of the development phase. Crop water requirement tends to increase in the next decade. During the development phase. The crop water requirement relatively the same which is about $42 \mathrm{~mm}$. From the mid-season phase to the end of the late-season phase. The crop water requirements continue to experience a slight fluctuation. In July. The crop water requirement decreases approaching the harvest. Also. In estimating the crop water requirements in intercropping of maize with soybeans are presented in Table VI.

There is a significant increase in the value of water needs in the flowering phase. Water requirements during vegetative and reproductive periods require considerable water. While the period leading up to harvest requires very 
little water [11], [22]. Then it also corresponds to the increased coefficient of the plant in the middle of the growing season and decreases at the end of the growing season. The reduction of water demand at reproductive phase can be explained by storage of higher soil moisture in the profile in the deep black soil and also less water requirement of the crop during maturity phase due to less green leaves [25], [26]. The result of this crop water requirement was obtained after the calculation using Cropwat 8.0 on each maize and soybean. The result of crop water requirement was summed. That is $408.6 \mathrm{~mm}$ for maize and $272.4 \mathrm{~mm}$ for soybean. The crops grown in the dry season needs more water than those grown during the rainy season in short-term crop. The range of water requirement for lowland rice was particularly high. Because the meteorological parameters were very high with less or no rainfall [11], [27], there are differences in the case of total water requirement for crops that the high productivity can be achieved with the optimum quantity of water if all other agronomic practices are followed [22].

However. If the estimation of crop water requirements in the intercropping pattern is compared with the estimation of crop water requirement in a single maize pattern. Then the estimated value of water demand obtained in single maize pattern is $408.6 \mathrm{~mm} / \mathrm{season}$. The value obtained in the single maize pattern is different from the intercropping pattern. Maize used either in single maize or intercropping pattern has the same varieties. The number of plants. The amount of plant area. The spacing between rows and other supporting factors. So that in the single pattern of maize obtained the same results of the crop water requirement as the amount of maize crop water requirement on the intercropping pattern before added to the amount of soybean water demand. This means that the amount of crop water requirement in a single maize pattern is smaller than the intercropping maize pattern. This is caused by the calculated Kc value for intercropping is different from $\mathrm{Kc}$ in the single maize pattern. The study is calculated by rainfall than with the estimation of the water requirement. Can meet the water needs in the plant. This can be seen physically from the results of good plant growth and not experiencing drought stress. Water is important to the plant as a solvent, a cooling agent, and as a reagent. For maintaining structure by keeping the pressure inside cells high enough so that they are fully expanded (i.e.. turgid). When the plant wilts. Its turgor approaches zero. The cells begin to collapse. Membranes suffer damage and proteins such as key enzymes can be denatured as their structure is altered. Cells can recover from drought stress. However, the damage must be repaired. And this takes time (0.5 to 7 days). If the damage is too great. the cells die [23], [28].

Water stress or drought stress in plants is a condition of plants that metabolism and its growth is disrupted by lack of water. Drought or submerged water due to the amount and timing of water supply is not appropriate and by the needs of plants. The direct effect of water stress on plant physiology is dehydration[23]. The first symptom apparent from dehydration is white red. However. The occurrence of water needs does not affect the growth of plants. Because the maize that was accompanied in this study showed tolerant to drought stress despite experiencing water shortage. Therefore. A drought tolerant variety was considered to have greater rooting density with depth in the soil profile for greater access and extraction of soil water. The drought tolerance of the maize varieties was enhanced by changing the relative root distribution function and the lower limit of soil water availability. Which is the level of soil water below which roots cannot extract water from the soil. for each soil layer[22], [29].

The value crop water requirement can be a reference to provide irrigation in plants. Especially in the dry season. In this study. Irrigation water was not provided but only used rainfall during the growing season from February to July. Based on water requirements that were obtained. The value of can is used as an evaluation by looking at the value of yield reduction or decrease in yields.

\section{E. Crop Productivity}

Maize is harvested when the plants are already browned. Corn kernels and filled with the color of reddish-orange seeds. The cornhusk begins to dry. Rice crops are harvested when the panicle is yellow, and paddy grains are fully loaded with rice. By using the software, Cropwat 8.0 can be known the possibility of decreasing results that will occur which is influenced by the crop water requirement and the irrigation provision. Maize in intercropping with rice with crop water requirement of $406.3 \mathrm{~mm}$ showed the productivity value was 7.454 ton/ha of the dry kernel. In the intercropping pattern of maize with soybean. The productivity value of maize is 7.88 ton/ha of the dry kernel. Based on the comparison of the production values. The productivity of maize is better if planted with intercropping pattern with soybeans. Although the number of productivity still in the range number of 7 tons/ha. The value of maize and soybean productivity is higher.

\section{CONCLUSIONS}

Based on the result of the study, the crop water requirement of maize intercropping with rice is $406.3 \mathrm{~mm}$. While the crop water requirement of maize intercropping with soybean is $408.6 \mathrm{~mm}$. The average productivity of maize on intercropping with rice is 7,454 ton/ha of the dry kernel, whereas, in intercropping of maize with soybean, productivity value of maize is 7.88 ton/ha of the dry kernel. The best combination, according to the productivity and the crop water requirement, is the maize intercropping with soybean. The difference in productivity is up to 5.7 percent with only $2.3 \mathrm{~mm}$ additional water requirement then maize intercropping with rice.

\section{ACKNOWLEDGMENT}

The authors would like to thank the Ministry of Research and Technology, and Higher Education who has funded this research through the scheme of Research Excellence of Higher Education (PUPT) in 2016.

\section{REFERENCES}

[1] F. Rhoads and C. Yonts, "Irrigation Scheduling for Corn — Why and How," National Corn Handbook, no. October, Iowa, 2000.

[2] J. Zhao and X. Yang, "Distribution of high-yield and high-yieldstability zones for maize yield potential in the main growing regions in China," Agric. For. Meteorol, vol. 248, no. October 2017, pp. 511-517, 2018. 
[3] J. P. Monzon, V. O. Sadras, and F. H. Andrade, "Modelled yield and water use efficiency of maize in response to crop management and Southern Oscillation Index in a soil-climate transect in Argentina," $F$. Crop. Res., vol. 130, pp. 8-18, 2012.

[4] D. K. S. Swastika et al., Maize in Indonesia: production systems, constraints and research priorities. Mexico: International Maize and Wheat Improvement Center (CIMMYT), 2004.

[5] D. B. Utomo and D. Ph, "Indonesian Maize Production and Trading for Feed," in Proceeding International Maize Conference: Agribusiness of Maize-Livestock Integration, 2012, pp. 53-57.

[6] Haryono, "Maize for Food, Feed and Fuel in Indonesia: Challenges and Opportunity," in Proceeding International Maize Conference: Agribusiness of Maize-Livestock Integration, 2012, pp. 3-9.

[7] F. Hu et al., "Intercropping maize and wheat with conservation agriculture principles improves water harvesting and reduces carbon emissions in dry areas," Eur. J. Agron., vol. 74, pp. 9-17, 2016.

[8] C. Johansen, M. E. Haque, R. W. Bell, C. Thierfelder, and R. J. Esdaile, "Conservation agriculture for small holder rainfed farming: Opportunities and constraints of new mechanized seeding systems," F. Crop. Res., vol. 132, pp. 18-32, 2012.

[9] D. Ruswandi et al., "Determination of Combining Ability and Heterosis of Grain Yield Components for Maize Mutants Based on LinexTester Analysis," Asian J. Crop Sci., vol. 7, no. 1, pp. 19-33, 2015.

[10] Y. Yuwariah, J. Supriatna, A. Nuraini, N. P. Indriani, A. T. Makkulawu, and D. Ruswandi, "Screening of Maize Hybrids under Maize / Soybean Intercropping Based on Their Combining Abilities and Multiple Cropping Components," Asian J. Crop Sci., vol. 10, no. 2, pp. 93-99, 2018.

[11] E. Suryadi, D. R. Kendarto, B. A. Sistanto, D. Ruswandi, and S. Dwiratna, "A Study of Crop Water Needs and Land Suitability in the Monoculture System and Plant Intercropping in Arjasari," Int. J. Adv. Sci. Eng. Inf. Technol., vol. 8, no. 2, pp. 554-560, 2018.

[12] S. Dwiratna, N. Bafdal, C. Asdak, and N. Carsono, "Study of Runoff Farming System to Improve Dryland Cropping Index in Indonesia," Int. J. Adv. Sci. Eng. Inf. Technol., vol. 8, no. 2, pp. 390-396, 2018.

[13] B. Nurpilihan, S. Dwiratna, and D. R. Kendarto, "Differences Growing Media In Autopot Fertigation System And Its Response To Cherry Tomatoes Yield," Indones. J. Appl. Sci., vol. 7, no. May 2016, pp. 63-68, 2017.

[14] L. Zhao, J. Xia, C. yu Xu, Z. Wang, L. Sobkowiak, and C. Long, "Evapotranspiration estimation methods in hydrological models," $J$. Geogr. Sci., vol. 23, no. 2, pp. 359-369, 2013.

[15] R. G. Allen, L. S. Pereira, D. Raes, and M. Smith, "Crop evapotranspiration: Guidelines for computing crop requirements," Irrig. Drain. Pap. No. 56, FAO, no. 56, p. 300, 1998.

[16] D. M. Sumner and J. M. Jacobs, "Utility of Penman-Monteith, Priestley-Taylor, reference evapotranspiration, and pan evaporation methods to estimate pasture evapotranspiration," J. Hydrol., vol. 308, no. $1-4$, pp. 81-104, 2005.

[17] U. Surendran, C. M. Sushanth, G. Mammen, and E. J. Joseph,
"Modelling the Crop Water Requirement Using FAO-CROPWAT and Assessment of Water Resources for Sustainable Water Resource Management: A Case Study in Palakkad District of Humid Tropical Kerala, India," Aquat. Procedia, vol. 4, no. Icwrcoe, pp. 1211-1219, 2015.

[18] O. Toda, K. Yoshida, S. Hiroaki, H. Katsuhiro, and H. Tanji, "Estimation of Irrigation Water Using Cropwat Model at $\mathrm{Km} 35$ Project Site, in Savannakhet, Lao PDR," in Role of Water Sciences in Transboundary River Basin Management, 2005, pp. 17-24.

[19] P. Banik and S. Ranjan, "CROPWAT Crop Water Assessment of Plain and Hilly Region Using CROPWAT Model," Int. J. Substainable Mater. Process. ECO-Efficient-IJSMPE, vol. 1, no. 3, pp. 1-9, 2014.

[20] F. Zhiming, L. I. U. Dengwei, and Z. Yuehong, "Water Requirements and Irrigation Scheduling of Spring Maize Using GIS and CropWat Model in Beijing-Tianjin-Hebei Region," vol. 17, no. 1, pp. 56-63, 2007.

[21] T. Erkossa, A. Haileslassie, and C. MacAlister, "Enhancing farming system water productivity through alternative land use and water management in vertisol areas of Ethiopian Blue Nile Basin (Abay)," Agric. Water Manag., vol. 132, pp. 120-128, 2014.

[22] X. Li, S. Kang, X. Zhang, F. Li, and H. Lu, "Deficit irrigation provokes more pronounced responses of maize photosynthesis and water productivity to elevated CO2," Agric. Water Manag., vol. 195, pp. 71-83, 2018.

[23] J. A. Tolk, S. R. Evett, W. Xu, and R. C. Schwartz, "Constraints on water use efficiency of drought tolerant maize grown in a semi-arid environment," F. Crop. Res., vol. 186, pp. 66-77, 2016.

[24] C. Yang, H. Fraga, W. Van Ieperen, and J. A. Santos, "Assessment of irrigated maize yield response to climate change scenarios in Portugal," Agric. Water Manag., vol. 184, pp. 178-190, 2017.

[25] Y. Wu, F. Huang, Z. Jia, X. Ren, and T. Cai, "Response of soil water, temperature, and maize (Zea may L.) Production to different plastic film mulching patterns in semi-arid areas of northwest China," Soil Tillage Res., vol. 166, pp. 113-121, 2017.

[26] M. Devkota et al., "Field Crops Research Combining permanent beds and residue retention with nitrogen fertilization improves crop yields and water productivity in irrigated arid lands under cotton, wheat and maize," F. Crop. Res., vol. 149, pp. 105-114, 2013.

[27] Y. Shen, S. Li, Y. Chen, Y. Qi, and S. Zhang, "Estimation of regional irrigation water requirement and water supply risk in the arid region of Northwestern China 1989-2010," Agric. Water Manag., vol. 128, pp. 55-64, 2013.

[28] M. Kercheva and Z. Popova, "Use of Irrigation Requirements and Scheduling as Drought Indicator Maize growth stages phases Sowing Late germination," in BALWOIS 2010, 2010, no. May, pp. 19811984.

[29] K. Sreelash, S. Buis, M. Sekhar, L. Ruiz, S. Kumar Tomer, and M. Guérif, "Estimation of available water capacity components of twolayered soils using crop model inversion: Effect of crop type and water regime," J. Hydrol., vol. 546, pp. 166-178, 2017. 